\title{
REVIVING PROSPECTS FOR LAKE RESTORATION - INVESTIGATING THE GEOCHEMISTRY OF LAKE ALÜKSNE SEDIMENTS
}

\author{
Oskars Purmalis ${ }^{1}$, Juris Burlakovs ${ }^{1,2}$ \\ ${ }^{1}$ University of Latvia \\ ${ }^{2}$ Linnaeus University, Sweden \\ oskars.purmalis@lu.lv
}

\begin{abstract}
Lake sediments have a broad range of elementary and organic substance content. Bottom sediments collect decaying organic debris of aquatic plants and animals mixed by water drift with mineral constituents - deposited in the bottom of the lake in anoxic conditions. Lake Alūksne is situated in Northeast Latvia and is of glacial origin. Its water and bottom sediments chemical content depends on formation conditions - influenced also by anthropogenic activities. In order to determine environmental quality for restoration purposes and sediment recovery, geochemical research is needed. This paper aims to study bottom sediments - texture, ash part, organic compounds and metals to pinpoint necessary steps that are crucial for distinguishing environmental quality of the lake through geochemistry research. Bottom sediments contain sapropel with large admixture of organic compounds and microelements that may significantly influence biota and human health if concentration exceeds natural background levels. When bottom sediments are recovered, it may improve oxygene conditions in the lake, extracted sapropel can be used as a fertilizer, therapeutic agents, supplements for farm foods. Generally, sapropel is improving the structure of agricultural soils, increasing the cation exchange capacity and serving as binding material for complexes formation; thus diminishing ecotoxicological exposure threats of heavy metals, increasing yields and albumen and protein quantity in plants cultivation products. As these sediments can be used for soil fertilizing and crop production improvement in agriculture, mechanisms of ecotoxicological impact to various soil types and agricultural plant ecology should be researched.
\end{abstract}

Key words: ecotoxicology, contamination, organic fertilizers, resources, microelements.

\section{Introduction}

Lakes carry the history of natural and anthropogenic impact in previous times. Physical and chemical data that is gained from lake sediments or soils in coastal neighbourhood can tell a lot, e.g., identifying deposition and erosion processes as well as underlying lithologies (Anselmetti et al., 2004; Beres et al., 2006; Drew et al., 2010; Grunsky et al., 2010, 2013, 2014). Geochemical data includes plethora of exploration, visualisation and meta-analysis of gained information (Grunsky, 2010). Inorganic and organic substances play a huge role in determining the environmental quality and interactions in ecosystems of water bodies (Burlakovs, 2008; Grunsky et al., 2012, 2013).

Apart from direct pollution such as heavy metals and organic contaminants, aquatic ecosystems can receive the so called nutrients from human generated both point sources (industrial and urban sewage) and non-point (leaching of agricultural N, P and atmospheric deposition of $\mathrm{N}$ compounds from fossil fuel combustion) (Burlakovs et al., 2013b). A lot of nutrients are coming from synthetic $\mathrm{N}$ fertilizers used and produced for decades (Howarth, 2008; Tao et al., 2017). Eutrophication in many freshwater systems is under danger (Basu et al., 2010). Sediment is an integral part of aquatic system and N, P-loading is dominant eutrophication factor (Romo et al., 2007). Wetlands and lake areas provide us with important ecosystem services (Postel \& Carpenter, 1997); nevertheless, there is a need to define the ecological quality whenever there is a need to revitalize or protect the natural habitats (Alvarez-Cobelas et al., 2001). One of influencing factors is intensive agriculture combined with industrial and common sense attitudes created surface and groundwater quality disturbances, these are the major threats for later absorbance of contaminants in bottom sediments and further development of poisoned food chains (Tockner \& Stanford, 2002; Burlakovs et al., 2013b; Tao et al., 2017). Therefore, a lot of water covered areas such as lakes and wetlands are included in Biosphere reserves by UNESCO, as Ramsar sites and/or refuges for migratory birds and aquatic plants (Cirujano et al., 1996). However, every lake in the nature demands the best available attitude and concerns if significant threats to environmental quality appear there.

Sediment geochemistry in lakes are archives for studying long-term fluctuations of environmental conditions, climate, history of vegetation and human impact (Meyers, 2003). These insights are used in forecasting of ecosystem in future (Wetzel, 2001). In eutrophic lakes dominant in North Temperate Zone, algae and macrophytes dominate instead of mineralization processes in lakes (Cooke et al., 2005). Therefore, thick organic layers of gyttja form very often (Hansen, 1959). Gyttja or sapropel may be also prospective material for applications (Stankevica \& Klavins, 2013; Stankevica \& Vincevica-Gaile, 2017) and lake restoration combined with material recovery (Stankevica et al., 2013, 2014; VincevicaGaile et al., 2015), but analysis of sediment composition from pollutants point of view is of 
great importance, helpful in reconstructions of industrial activities and raising understanding on aims that should be reached through ecosystem revitalization. Several lakes in Latvia have been intensively studied through scientific and applied research activities, some of them are tended and supported by municipalities that want to promote site clean-up for better local environmental quality (Purmalis et al., 2017; Burlakovs et al., 2016; Stankevica et al., 2015; Vircavs, 2006).

In turn of the 21th century up till now a lot of research had been done around. This paper describes the sediment quality in Lake Alūksne of glacial origin in Northeast Latvia. The aim of this paper is to pinpoint necessary steps that are crucial for distinguishing environmental quality of the lake sediments (probably polluted) through geochemistry research, both organic and inorganic substances. Following tasks were defined and fulfilled: 1) visual assessment and core sampling of sediments; 2) determination of basic parameters for sediments and textural properties; 3) measuring $\mathrm{C}, \mathrm{N}, \mathrm{P}$ elemental concentrations mainly responsible for eutrophication processes; 4) analyses of $\mathrm{Pb}, \mathrm{Zn}, \mathrm{Cu}, \mathrm{Cr}, \mathrm{Ni}, \mathrm{Cd}$ and $\mathrm{As}$ to guideline exposure to toxic inorganics; 5) measurements of concentration for total hydrocarbons, polycyclic aromatic hydrocarbons (PAH) and polychlorinated biphenyls
(PCB) in sediments; 6) analysis of data and providing recommendations.

\section{Materials and Methods}

Lake Alūksne (Fig. 1) is relatively deep lake of Pleistocene glacial origin in Alūksne Highland developed in glacial environment. At present times, Lake Alūksne in its deepest part is $20.0 \mathrm{~m}$ deep, but the average depth is $6.7 \mathrm{~m}$. It has four islands and is situated $>180 \mathrm{~m}$ osl. Coasts of the lake are hilly, at several places they are urban and severely urbanized nearby the gulf where the investigation was concentrated on. Sediment samples of various types were derived from rich organic sediment layers (Figure 1).

Sediment sampling cores in lakes were performed in certain points selected according to the established network and coupled with sampling. Texture analysis, elemental and moisture content, loss of ignition (LOI) and $\mathrm{pH}$ were determined. Mostly organic material, mud and gyttja (sapropel) are covering mineral soil layer which is mostly sand, gravelly sand and rarely glacial till. The upper part consists of mud with low plasticity, deeper layered sapropel.

Coring of sediments was done using a Russiantype sampler equipped with a $1.0 \mathrm{~m}$ long $(\mathrm{d}=5 \mathrm{~cm})$ camera. Every sample was put into a non-transparent

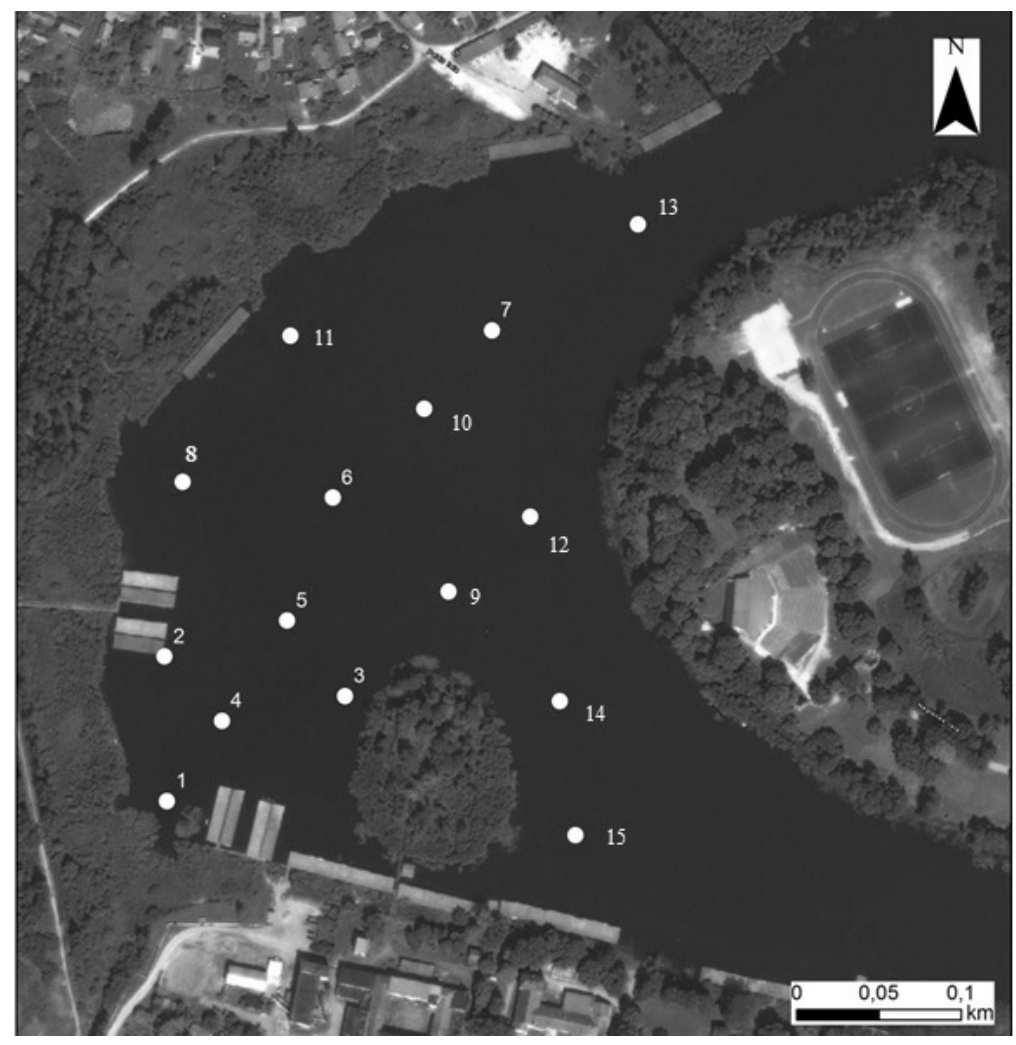

Figure 1. Map of location of sediment sampling points in Lake Alūksne, Southwestern part nearby urbanized areas with potential contamination. 
air-tight plastic bucket with a lid and stored at constant temperature $\left(+4{ }^{\circ} \mathrm{C}\right)$ to achieve in situ conditions during the storage. Sediment core was characterised by type of sediments.

Loss on ignition (LOI) method was applied for sediment analysis in order to estimate the moisture level and content of organic matter, carbonates and mineral matter in the sediments (Heiri et al., 2001). Moisture of sediments was determined after drying samples at $105^{\circ} \mathrm{C}$ in drying oven. Content of organic and carbonate matter was analyzed by incinerating the samples sequentially at $550{ }^{\circ} \mathrm{C}$ for $4 \mathrm{~h}$ and at $900{ }^{\circ} \mathrm{C}$ for $2 \mathrm{~h}$.

Quantitative content of metals in sediment was measured by atomic absorption spectrometry (AAS) (PerkinElmer AAnalyst 200) and total reflection X-ray fluorescence spectrometer (Röntec PicoTAX). Samples were mineralized in analytical-grade $\mathrm{HNO}_{3}$ and $\mathrm{H}_{2} \mathrm{O}_{2}$ mixture. Total amount of $\mathrm{C}, \mathrm{N}$ were determined with element analyzer (Eurovector). Total $\mathrm{P}$ was analyzed using ascorbic acid method (Hieltjes et al., 1980).

For the measurement of total hydrocarbons, fractions of hydrocarbons as well as $\mathrm{PAH}$, samples were extracted in double distilled hexane and analyzed with gas-chromatography (Shimadzu GC-2010 Plus). The method used for extracting the PCBs from sediments was modified from the US EPA Method (USEPA, 1996). Sediment (30 g) (triplicates were made for each sample) was extracted for $8 \mathrm{~h}$ using the Soxhlet instrument with $200 \mathrm{ml}$ (1:1) of $n$-hexane$\mathrm{CH}_{2} \mathrm{Cl}_{2}$. Prepared extracts were analyzed with gaschromatography (Shimadzu GC-2010 Plus).

\section{Results and Discussion}

Watershed and location in highland and city of studied lake have influenced sediment accumulation whose total depth in researched gulf reaches up to 13 $\mathrm{m}$. The deepest part of lakes $(>2.5 \mathrm{~m})$, its sediment consists of organic matter $\sim 64 \%$, carbonates $\sim 2 \%$ and mineral sediments $\sim 33 \% ; 250-100 \mathrm{~cm}$ deep organic matter reaches $\sim 70 \%$, but shallower parts of the lake nearby coastline only $20-30 \%$. Sediments with clearly identified anthropogenic origin contain $\sim 10 \%$ of organic matter. Discovered variation of organic matter content in sediment causes material input from watershed of lake as well as from city. In some areas in lake sediments anthropogenic input from former wastewater source reaches thickness about $1 \mathrm{~m}$. These findings provide answer to the question about factors responsible for rapid loss of water depth in the gulf of lake. In shallow water, intensive spreading of macrophytes increases, indicating beginning of eutrophication. Although $\mathrm{N}: \mathrm{P}$ ratio of sediments is relatively high representing oligotrophic waters (Geider et al., 2002), but high C/N ratio (Table 1) indicates a prevailing allochthonous source of organic matter (Guilizzoni et al., 1996). Prospective overgrowing of researched gulf in the current development stage of lake is inevitable, thus highlighting importance of possible restoration.

In the researched gulf of lake in past decades manufactures of city have discharged their wastewaters. There is no exact data about total amount and quality of wastewaters, but there has been suspicion that sediment may be polluted, probably with oil products; therefore, total amount of oil products in sediments were analyzed on organics, including polycyclic aromatic hydrocarbons (PAHs) and polychlorinated biphenyls (PCBs). The analysis of sediments shows relatively high concentrations of total amount of oil products exceeding not only in natural conditions background amount (Abdel-Shafy et al., 2016) $\left(<100 \mathrm{mg} \mathrm{kg}^{-1}\right)$, but also authorities posted regulations $\left(>400 \mathrm{mg} \mathrm{kg}^{-1}\right)$.

Total amount of oil products in sediments (Table 2) clearly represents human impact with source next to sampling point No.1. Contamination of oil products in the lake diffuses close by source due to lack of hydrological dynamics and properties of pollutant. Moreover, behavior of these products shows no or insignificant infiltration rate probably by binding with organic matter in sediments. Pollution has not migrated from the source further than $400 \mathrm{~m}$ and most of mass accumulates next by inlet. PAH's results show even smaller migration capacity due to their

Element composition and their relations of sediment cover in Lake Alūksne ( $\left.\mathrm{g} \mathrm{kg}^{-1}\right)$

\begin{tabular}{|c|c|c|c|c|c|}
\hline No. & $\mathrm{N}$ & $\mathrm{C}$ & $\mathrm{P}$ & $\mathrm{N} / \mathrm{C}$ & $\mathrm{C}: \mathrm{N}: \mathrm{P}$ \\
\hline 1 & 19.1 & 226.5 & 0.555 & 0.084 & $407: 34: 1$ \\
\hline 2 & 24.8 & 253.4 & 0.564 & 0.098 & $456: 45: 1$ \\
\hline 3 & 21.6 & 230.3 & 0.509 & 0.094 & $415: 39: 1$ \\
\hline 5 & 21.6 & 232.7 & 0.497 & 0.093 & $419: 39: 1$ \\
\hline 6 & 25.6 & 254.0 & 0.542 & 0.100 & $457: 46: 1$ \\
\hline 7 & 26.1 & 266.7 & 0.524 & 0.098 & $480: 47: 1$ \\
\hline
\end{tabular}


nature (Dąbrowska et al., 2008) and low solubility in water (Abdel-Shafy et al., 2016). Concentration as well as amount of pollutants steeply decreases starting from sampling point no.1 which strongly correlates with organic matter/ash content detected with LOI (Heiri et al., 2001) and pH, suggesting that organic pollutants form complexes with organic matter (humic substances) (Klavins et al., 2011; Burlakovs et al., 2013a) also approved by $\mathrm{pH}$ measurements. Average $\mathrm{pH}$ value of sediments is 6.0 , but in sampling point no.5 in upper layers $\mathrm{pH}$ value reaches up to 6.81 and in no. 1 up to 7.95 due to nature of PAH's, their concentration, neutralization of carboxylic groups of humic substances (Klavins et al., 2010) as well as possible toxicity (quiet low) to microorganisms (Abdel-Shafy et al., 2016). Although the greatest degradation rates at soil are at $\mathrm{pH} 7.5$ (Pawar et al., 2015), at the same time during microbial degradation $\mathrm{pH}$ value can decrease up to 5.8 (Yenn, 2015) which strongly depend on species of microorganisms and abiotic factors.

To describe sediments polluted with oil better, the analysis of fractional content of hydrocarbons has been done for two samples (No. 1: $43-80 \mathrm{~cm}$; No.
4: $10-30 \mathrm{~cm}$ ) representing upper layer of sediments and layer with highest oil concentration. Fractions of hydrocarbons were divided to $\mathrm{C}_{6}-\mathrm{C}_{10}$ (light fraction representing petrol, petrol ether); $\mathrm{C}_{10}-\mathrm{C}_{24}$ (kerosene, diesel, aviation petrol); $\mathrm{C}_{24}-\mathrm{C}_{40}$ (motor oil, paraffin waxes, mazut). Results show that more than $80 \%$ are heavy fractions of hydrocarbons in No.1. $\mathrm{C}_{6}-\mathrm{C}_{10}-$ $0.3 \% ; \mathrm{C}_{10}-\mathrm{C}_{24}-19.1 \% ; \mathrm{C}_{24}-\mathrm{C}_{40}-80.6 \%$, but in No.4, it is, $1.2 \% ; 13.7 \% ; 85.1 \%$ respectively.

Content of PAHs clearly shows their presence in lake sediments due to emitting polluted wastewaters form manufactures in Alūksne city. In the result, not only total amount is relatively high but also analysis of individual compounds of PAHs demonstrates significant level of sediment contamination (Table 3).

Distinguishing features of distribution patterns of PAH's and dominance of anthracene and other widely existing PAH's suggesting that source is pyrogenic and may be oil and burn residues (Wang et al., 2005; Abdel-Shafy et al., 2016). Similarly to oil products in this particular lake, also PAH's are surrounded with organic matter and therefore encapsulated. Reasons may be strong degradation product complexation with organic matter. Anthracene is the compound

Table 2

Total hydrocarbons, polycyclic aromatic hydrocarbon (PAH) and polychlorinated biphenyls (PCB) in sediments of Lake Alūksne

\begin{tabular}{|c|c|c|c|c|c|c|c|}
\hline $\begin{array}{c}\text { Sampling } \\
\text { No. }\end{array}$ & Depth, cm & $\begin{array}{c}\text { Total } \\
\text { hydrocarbons, } \\
\mathrm{mg} \mathrm{kg}^{-1}\end{array}$ & $\begin{array}{c}\text { Polycyclic } \\
\text { aromatic } \\
\text { hydrocarbon, } \\
\mu \mathrm{gg}^{-1}\end{array}$ & $\begin{array}{c}\text { Polychlorinated } \\
\text { biphenyls, } \mu \mathrm{g} \\
\mathrm{kg}^{-1}\end{array}$ & $\begin{array}{c}\text { Sampling } \\
\text { No. }\end{array}$ & $\begin{array}{l}\text { Depth, } \\
\mathrm{cm}\end{array}$ & $\begin{array}{c}\text { Total } \\
\text { hydrocarbons, } \\
\mathrm{mg} \mathrm{kg}^{-1}\end{array}$ \\
\hline \multirow{5}{*}{1} & $0-43$ & 513 & n.a. & n.a. & \multirow{2}{*}{8} & $10-30$ & 302 \\
\hline & $43-80$ & 906 & 3585 & 90 & & $50-70$ & 29 \\
\hline & $110-140$ & 149 & 5549 & 66 & \multirow{2}{*}{9} & $10-30$ & 34 \\
\hline & $170-190$ & 169 & n.a. & n.a. & & $50-70$ & 35 \\
\hline & $200-210$ & 169 & n.a. & n.a. & \multirow{2}{*}{10} & $10-30$ & 189 \\
\hline \multirow{2}{*}{2} & $10-30$ & 278 & 4554 & n.a. & & $50-70$ & 24 \\
\hline & $60-80$ & 208 & n.a. & n.a. & 11 & $10-30$ & 27 \\
\hline \multirow{2}{*}{3} & $10-30$ & 302 & 4344 & n.a. & 12 & $10-30$ & 81 \\
\hline & $50-70$ & 194 & n.a. & n.a. & 13 & $10-30$ & 32 \\
\hline \multirow{3}{*}{4} & $10-30$ & 274 & 1753 & 63 & 14 & $10-30$ & 73 \\
\hline & $50-70$ & 222 & 6634 & n.a. & 15 & $10-30$ & 51 \\
\hline & $80-100$ & 229 & n.a. & n.a. & & & \\
\hline \multirow{3}{*}{5} & $10-30$ & 508 & 1015 & 4 & & & \\
\hline & $50-70$ & 153 & 1223 & 14 & & & \\
\hline & $80-100$ & 100 & 347 & n.a. & & & \\
\hline \multirow{2}{*}{6} & $10-30$ & 291 & 2732 & n.a. & & & \\
\hline & $50-70$ & 150 & n.a. & n.a. & & & \\
\hline \multirow{2}{*}{7} & $10-30$ & 343 & 1010 & n.a. & & & \\
\hline & $50-70$ & 87 & 255 & n.a. & & & \\
\hline
\end{tabular}


Table3

Individual compounds of polycyclic aromatic hydrocarbon (PAH) in sediments of Lake Alūksne $\left(\mu \mathrm{kg}^{-1}\right)$

\begin{tabular}{|l|c|c|c|c|c|c|c|c|c|c|c|c|}
\hline Sampling No. & \multicolumn{2}{|c|}{1} & 2 & 3 & \multicolumn{2}{|c|}{4} & \multicolumn{3}{|c|}{5} & 6 & \multicolumn{2}{c|}{7} \\
\hline Depth, cm & $43-80$ & $\begin{array}{c}110- \\
140\end{array}$ & $\begin{array}{c}10- \\
30\end{array}$ & $10-30$ & $10-30$ & $50-70$ & $10-30$ & $\begin{array}{c}50- \\
70\end{array}$ & $\begin{array}{c}80- \\
100\end{array}$ & $\begin{array}{c}10- \\
30\end{array}$ & $\begin{array}{c}10- \\
30\end{array}$ & $\begin{array}{c}50- \\
70\end{array}$ \\
\hline Naphthalene & 77.2 & 54.4 & 9.3 & 33.9 & 63.0 & 90.7 & 31.3 & 14.1 & 9.6 & 8.3 & 10.3 & 9.4 \\
\hline Phenanthrene & 465.6 & 836.9 & 40.6 & 70.9 & 129.1 & 763.6 & 97.3 & 19.8 & 7.1 & 30.6 & 13.0 & 7.7 \\
\hline Anthracene & 465.6 & 170.3 & 8.4 & 21.2 & 129.1 & 150.8 & 25.9 & 4.6 & 1.6 & 6.1 & 3.0 & 1.5 \\
\hline Fluoranthene & 465.2 & 377.2 & 79.0 & 119.7 & 287.9 & 331.7 & 165.7 & 28.7 & 7.7 & 38.6 & 20.9 & 7.0 \\
\hline Benz[a]anthrace & 238.5 & 434.0 & 56.3 & 19.5 & 118.1 & 283.4 & 28.3 & 4.3 & 1.1 & 28.2 & 3.4 & 0.8 \\
\hline Chrysene & 376.7 & 168.4 & 32.2 & 53.5 & 118.1 & 109.5 & 81.9 & 12.7 & 3.4 & 14.5 & 9.3 & 2.3 \\
\hline $\begin{array}{l}\text { Benzo[k] } \\
\text { fluoranthene }\end{array}$ & 275.6 & 118.9 & 39.8 & 27.5 & 174.7 & 61.6 & 46.3 & 8.7 & 2.9 & 22.1 & 8.3 & 2.1 \\
\hline Benzo[a]pyrene & 417.8 & 251.8 & 60.1 & 44.6 & 374.4 & 137.1 & 64.7 & 9.8 & 2.6 & 27.2 & 10.2 & 2.1 \\
\hline $\begin{array}{l}\text { Indeno[1,2,3- } \\
c, d] p y r e n e\end{array}$ & 20.4 & 1.9 & 52.8 & 40.6 & 106.6 & 83.3 & 63.8 & 17.8 & 6.2 & 33.1 & 16.9 & 3.7 \\
\hline $\begin{array}{l}\text { Benzo[g,h,i] } \\
\text { perylen }\end{array}$ & $<15$ & 2.2 & 73.5 & 90.0 & $<15$ & 2.6 & 129.4 & 30.8 & 10.8 & 42.4 & 34.6 & 6.9 \\
\hline
\end{tabular}

Content of heavy metals $\left(\mathrm{mg} \mathrm{kg}^{-1}\right)$ in sediments of Lake Alūksne

Table 4

\begin{tabular}{|c|c|c|c|c|c|c|c|c|}
\hline \multirow{2}{*}{\multicolumn{2}{|c|}{ Sampling No. and depth, cm }} & $\mathrm{Cr}$ & $\mathrm{Ni}$ & $\mathrm{Cu}$ & $\mathrm{Zn}$ & $\mathrm{Cd}$ & $\mathrm{Pb}$ & As \\
\hline & & $\mathrm{mg} \mathrm{kg}^{-1}$ & $\mathrm{mg} \mathrm{kg}^{-1}$ & $\mathrm{mg} \mathrm{kg}^{-1}$ & $\mathrm{mg} \mathrm{kg}^{-1}$ & $\mathrm{mg} \mathrm{kg}^{-1}$ & $\mathrm{mg} \mathrm{kg}^{-1}$ & $\mathrm{mg} \mathrm{kg}^{-1}$ \\
\hline \multirow{9}{*}{1} & $0-15$ & 11.3 & 9.5 & 16.3 & 66.4 & 0.08 & 4.1 & $<0.7$ \\
\hline & $40-50$ & 10.1 & 8.5 & 17.3 & 85.9 & 0.29 & 7.1 & 1.1 \\
\hline & $70-80$ & 16.4 & 10.0 & 28.3 & 144.5 & 0.77 & 42.9 & $<0.7$ \\
\hline & $110-120$ & 83.5 & 12.0 & 45.9 & 207.9 & 0.59 & 73.5 & $<0.7$ \\
\hline & $140-150$ & 82.5 & 12.0 & 40.0 & 149.4 & 0.55 & 69.2 & $<0.7$ \\
\hline & $210-220$ & 14.6 & 9.1 & 21.5 & 77.3 & 0.24 & 15.2 & $<0.7$ \\
\hline & $250-260$ & 13.5 & 8.4 & 13.4 & 87.3 & 0.22 & 14.3 & $<0.7$ \\
\hline & $290-300$ & 10.6 & 11.1 & 23.8 & 76.0 & 0.22 & 9.6 & 1.4 \\
\hline & $380-390$ & 15.3 & 9.3 & 36.1 & 80.4 & 0.20 & 21.2 & 2.3 \\
\hline \multirow{10}{*}{5} & $10-20$ & 25.2 & 12.9 & 40.1 & 280.9 & 1.22 & 60.6 & $<0.7$ \\
\hline & $30-40$ & 23.0 & 12.7 & 48.5 & 249.3 & 1.10 & 69.2 & $<0.7$ \\
\hline & $50-60$ & 20.5 & 11.5 & 24.4 & 118.8 & 0.59 & 38.9 & $<0.7$ \\
\hline & $80-90$ & 10.0 & 7.7 & 12.5 & 77.0 & 0.23 & 11.6 & $<0.7$ \\
\hline & $110-120$ & 12.4 & 8.6 & 18.0 & 68.7 & 0.19 & 10.7 & $<0.7$ \\
\hline & $150-160$ & 15.2 & 8.2 & 10.0 & 75.5 & 0.21 & 14.2 & $<0.7$ \\
\hline & $180-190$ & 12.8 & 8.3 & 12.1 & 84.1 & 0.17 & 5.7 & $<0.7$ \\
\hline & $200-210$ & 16.1 & 10.1 & 12.5 & 73.1 & 0.22 & 9.4 & $<0.7$ \\
\hline & $230-240$ & 8.7 & 9.3 & 19.8 & 84.3 & 0.32 & 10.7 & $<0.7$ \\
\hline & $270-280$ & 17.0 & 10.1 & 11.0 & 69.5 & 0.17 & 5.8 & $<0.7$ \\
\hline
\end{tabular}

which very quickly underwent photodegradation yielding an thraquinone as the main degradation product (Dąbrowska et al., 2008), but major role to enhancing solubility of anthraquinone and their complexation plays humic substances (Klavins et $a l ., 2008)$. These reactions and heavy fractions and properties of pollutants are main reasons why deeper sediment layers as well as far away located sediments 
from inlet source do not show presence of enlarged oil and PAH's concentrations. Also, low solubility of PAH's in water (Abdel-Shafy et al., 2016) establishes their stability and low bioavailability and toxicity to food chains, for example, to fishes of Lake Alūksne (Rudovica et al., 2015).

Polychlorinated biphenyls were widely used as dielectric and coolant fluids in electrical apparatus and in heat transfer fluids affirming previously mentioned type of source - crude oil and burning residues. Because of their longevity and PCBs' environmental toxicity and high bioaccumulation rate, they have been classified as persistent organic pollutants (POPs) (Vorkamp, 2016). PCB production was banned for some time, but we still may detect these compounds in the environment till nowadays. Alongside increased concentration of heavy metals (Stankevica et al., 2015), also PCB's are distinctly correlated to human impact to environment. We have analyzed PCB's content in 5 samples and detected presence, hence amount which should take account before recovery activities - however PAH's may have elevated negative influence and risk to environment Individual compounds of PCB's have exceeded minimal requirements of government regulations up to $6-12 \mu \mathrm{g} \mathrm{kg}^{-1}$, but they are not even close to concentration which allocates studied sediment as contaminated.

The content of metallic elements in sediments was detected for 60 samples (10 samples per coring) dispersed to the max depth $3.9 \mathrm{~m}$. Despite the presence of organic pollutants, there was no identified contamination of heavy metals (Table 4). Metal concentrations did not exceed geochemical background and are very similar with concentrations in undisturbed natural lake sediments (Klavins et al., 1995; Klavins et al., 2001; Klavins et al., 2011). Although, when compared results, in sampling place no. 1 they differ with a little bit higher metal $(\mathrm{Pb}, \mathrm{Cu}$, $\mathrm{Zn}, \mathrm{Sn}, \mathrm{Cd}, \mathrm{Cr}$ ) concentrations due to composition of pollutant. Metal ions may be strongly correlated with oil and PAH contamination (not detected in deeper located sediments) - those in lake sediments are $\mathrm{Bi}$, Th, Y which can be concluded as pollution from former electro-technical factory, however concentrations are still slight and do not pose threats to environment and human health. Also, it was approved when tissues of fish were studied in Rudovica et al., 2015. Our research concluded that sediments shall be treated from hydrocarbons in urbanized gulf near Alūksne City, if sapropel is recovered, preliminary treatment is compulsory for further use as the resource.

\section{Conclusions}

The geochemical study in Lake Alūksne has shown that despite strong anthropogenic influence of emitted pollutants near Alūksne City, sediments are not strongly contaminated to put on the priority list for remediation. If sediments are extracted for lake remediation and possible resources recovery procedures, further research work must be performed in optimized mode in the gulf only. Crucial aspects in study success were careful preliminary studies of available geological and previously published data, careful interpretation of gained information on organic and inorganic contents in lake bottom sediments. Our research concluded that sediments shall be treated from hydrocarbons in urbanized gulf near Alūksne City, if sapropel is recovered, preliminary treatment is compulsory for further use as the resource.

\section{Acknowledgements}

This work was supported by University of Latvia grant 'Sustainable use of nature resources in the context of climate changes' Nr.AAP2016/B041, Linnaeus University and Geo IT Ltd. company.

\section{References}

1. Abdel-Shafy, H.I., Mansour, M.S.M. (2016). A review on polycyclic aromatic hydrocarbons: Source, environmental impact, effect on human health and remediation. Egyptian Journal of Petroleum, 25, $107-123$.

2. Alvarez-Cobelas, M., Cirujano, S., \& Sánchez-Carrillo, S. (2001). Hydrological and botanical man-made changes in the Spanish wetland of Las Tablas de Daimiel. Biol. Conserv., 97, $89-98$.

3. Anselmetti, F., Fuchs, M., \& Beres, M. (2004). Sedimentological Studies of Western Swiss Lakes with High Resolution Reflection Seismic and Amphibious. GPR Profiling, 10th international conference on ground penetrating radar, $21^{\text {st }}-24^{\text {th }}$ June, Delft, The Netherlands. DOI: 10.1109/ICGPR.2004.179809.

4. Basu, N.B., Destouni, G., Jawitz, J.W., Thompson, S.E., Loukinova, N.V., Darracq, A., Zanardo, S., Yaeger, M., Sivapalan, M., Rinaldo, A., Suresh, P., \& Rao, C. (2010). Nutrient loads exported from managed catchments reveal emergentbiogeochemical stationarity. Geophys. Res. Lett., 37(23), $400-404$.

5. Beres, M., Fuchs, M., Girardclos, S., Corboud, P., \& Sastre, V. (2006). Using High-Resolution Seismic and GPR Methods in Sedimentological Studies of the Geneva Bay Area (Switzerland). Near Surface $2006-$ Helsinki, Finland, $1-6$.

6. Burlakovs, J. (2008). Groundwater sampling for monitoring purposes: Case studies in Latvia. In: SGEM2008 Conference Proceedings, 1, 687 - 690. 
7. Burlakovs, J., Klavins, M., Ernsteins, R., \& Ruskulis, A. (2013b). Contamination in industrial sites and environmental management in Latvia. In: Proceedings of World Academy of Science, Engineering and Technology, Johannesburg, South Africa, 76, 463 - 468.

8. Burlakovs, J., Klavins, M., Osinska, L., \& Purmalis, O. (2013a). The Impact of humic substances as remediation agents to the speciation forms of metals in soil. In: Proceedings of APCBEES Procedia of 4th International Conference on Environmental Science and Development in Dubai, 5, 192 - 196.

9. Burlakovs, J., Purmalis, O., Krievans, M., \& Jani, Y. (2016). Ground-penetrating radar (GPR) geoenvironmental screening in lakes of Latvia: challenges and outcomes In: Proceedings of Near Surface Geoscience, Barcelona, EarthDoc, EAGE, We 22P1 14.

10. Cirujano, S., Casado, C., Bernués, M., \& Camargo, J.A. (1996). Ecological study of Las Tablas de Daimiel National Park (Ciudad Real, Central Spain): differences in water physicochemistry and vegetation between 1974 and 1989. Biol. Conserv., 75, $211-215$.

11. Cooke, G.D., Welch, E.B., Peterson, S.A., \& Nichols, S.A. (2005). Restoration and Management of Lakes and Reservoirs, third ed. CRC Press, New York.

12. Dąbrowska, D., Kot-Wasik, A., \& Namieśnik, J. (2008). Stability Studies of Selected Polycyclic Aromatic Hydrocarbons in Different Organic Solvents and Identification of Their Transformation Products. Polish J. of Environ. Stud., 17( 1), 17 - 24.

13. Drew, L.D., Grunsky, E.C., Sutphin, D.M., \& Woodruff, L.G. (2010). Multivariate analysis of the geochemistry and mineralogy of soils along two continental-scale transects in North America.Sci.Total Environ.,409, 218 - 227.

14. Geider, R., \& La Roche, J. (2002). Redfield revisited: variability of C:N:P in marine microalgae and its biochemical basis. European Journal of Phycology, 37(1), 1 - 17. DOI: 10.1017/S0967026201003456.

15. Grunsky, E.C. (2012). Editorial, special issue on spatial multivariate methods. Math. Geosci.,44(4), $379-380$.

16. Grunsky, E.C., Drew, L.D., \& Sutphin, D.M. (2010). Process recognition in multi-element soil and streamsediment geochemistry. Appl. Geochem., 24 (8), $1602-1616$.

17. Grunsky, E.C., Drew, L.J.,Woodruff, L.G., Friske, P.W.B., \& Sutphin, D.M. (2013). Statistical variability of the geochemistry and mineralogy of soils in the maritime provinces of Canada and part of the northeast United States, geochemistry: exploration. Environ. Anal., 13, 249 - 266. DOI: 10.1144/geochem2012-138.

18. Grunsky, E.C., Mueller, U.A., \& Corrigan, D. (2014). A study of the lake sediment geochemistry of the Melville Peninsula using multivariate methods: applications for predictive geological mapping. $J$. Geochem. Explor., 141, 15 - 41. DOI: 10.1016/j.gexplo.2013.07.013.

19. Guilizzoni, P., Marchetto, A., Lami, A., Cameron, N.G., Appleby, P.G., Rose, N.L., Schnell, Ø.A., Belis C.A., Giorgis, A., \& Guzzi, L. (1996). The environmental history of a mountain lake (Lago Paione Superiore, Central Alps, Italy) for the last c. 100 years: a multidisciplinary, palaeolimnological study. Journal of Paleolimnology, 15(3), 245 - 264. DOI: 10.1007/BF00213044.

20. Hansen, K. (1959). The terms Gyttja and Dy. Hydrobiologia, 13, $309-315$.

21. Heiri, O., Lotter, A.F., \& Lemcke, G. (2001). Loss on ignition as a method for estimating organic and carbonate content in sediments: reproducibility and comparability of results. Journal of Paleolimnology, $25,101-110$.

22. Howarth, R.W. (2008). Coastal nitrogen pollution: a review of sources trends globally and regionally. Harmful Algae, 8, 14 - 20.

23. Kḷaviņš, M., Briede, A., Kḷaviņa, I., \& Rodinov, V. (1995). Metals in sediments of lakes in Latvia. Environment International, 21(4), 451 - 458. DOI: 10.1016/0160-4120(95)00031-F.

24. Klavins, M., Ansone, L., Purmalis, O., \& Zicmanis, A. (2011). Characterization of interaction between tricyclic structures containing pharmaceuticals, their models and humic substances. Water Sci. \& Tech., $63.5,845-852$.

25. Klavins, M., Kokorite, I., Jankevica, M., Mazeika, J., \& Rodinov, V. (2011). Trace elements in sediments of lakes in Latvia. Recent Researches in Geography, Geology, Energy, Environment and Biomedicine, 43 - 47.

26. Klavins, M., \& Purmalis, O. (2010). Humic substances as surfactants. Environ Chem Lett., 8(4), 349 - 354.

27. Klavins, M., \& Vircavs, M. (2001). Metals in sediments of inland waters of Lativa. Boreal environmental research, 6, $297-306$.

28. Kḷaviņš, M., Zicmanis, A., \& Purmalis, O. (2008). Humic substances and their derivatives as surfactants. Latvijas Ķ̄mijas žurnāls, (3), $263-273$. 
29. Meyers, P.A. (2003). Applications of organic geochemistry to paleolimnological reconstructions: a summary of examples from the Laurentian Great Lakes. Organic Geochemistry, 34 (2), 261 - 289.

30. Pawar, R.M. (2015). The Effect of Soil pH on Bioremediation of Polycyclic Aromatic Hydrocarbons (PAHS). Journal of Bioremediation \& Biodegradation, 6(3), 1 - 14. DOI: 10.4172/2155-6199.1000291.

31. Postel, S., \& Carpenter, S. (1997). Freshwater ecosystemservices. In: Daily, G.C. (Ed.), Nature's Services: Societal Dependence on Natural Ecosystems. Island Pres, Washington, D.C., 195 - 214.

32. Purmalis, O., Alksnis, A., Taskovs, J., \& Burlakovs, J. (2017). Ground-penetrating radar (GPR) screening in shallow Engure and Pape lagoon lakes In: Proceedings of Research for Rural Development, $1,228-235$.

33. Romo, S., Villena, M.J., \& García-Murcia, A. (2007). Epiphyton, phytoplankton andmacrophyte ecology in a shallow lake under in situ experimental conditions.Fund. Appl. Limnol. 170, 197 - 209.

34. Rudovica, V., \& Bartkevics, V. (2015). Chemical elements in the muscle tissues of European eel (Anguilla anguilla) from selected lakes in Latvia. Environ Monit Assess, 187(608), 1 - 10. DOI: 10.1007/s10661015-4832-8.

35. Stankevica, K., \& Vincevica-Gaile, Z. (2017). Impact of micro- and macroelement content on potential use of freshwater sediments (gyttja) derived from lakes of eastern Latvia. Env Geochemistry and Health, in press,

36. Stankevica, K., Burlakovs, J., Klavins, M., \& Vincevica-Gaile, Z. (2014). Environmental and economic aspects of small freshwater lake sustainable use: Lake Pilvelis example. In: Proceedings of 14th SGEM GeoConference on Science and Technologies in Geology, Exploration and Mining, 5(3), 127 - 134.

37. Stankevica, K., Burlakovs, J., \& Klavins, M. (2013). Organic rich freshwater sediments (sapropel) as potential soil amendment for recultivation of contaminated with heavy metal compounds areas. In: Proceedings of 13th SGEM GeoConference on Water Resources. Forest, Marine and Ocean Ecosystems, $595-602$.

38. Stankevica, K., \& Klavins, M. (2013). Sapropel and Its Usage Possibilities. (Sapropelis un tā izmantošanas iespējas). Scientific Journal of RTU: Materials Sciences and Applied Chemistry, 29, 109 - 126.

39. Stankevica, K., Pujate, A., Kalnina, L., Klavins M., Cerina, A., \& Drucka, A. (2015). Records of the anthropogenic influence on different origin small lake sediments of Latvia. Baltica, 28(2), 135 - 150.

40. Tao, Y., Xue, B., Lei, G., Liu, F., \& Wang, Z. (2017). Effects of climate change on bioaccumulation and biomagnification of polycyclic aromatic hydrocarbons in the planktonic food web of a subtropical shallow eutrophic lake in China. Environmental Pollution, 223, 624 - 634.

41. Tockner, K., \& Stanford, J.A. (2002). Riverine flood plains: present state and future trends. Environ. Conserv., 29, $308-330$.

42. USEPA (1996). Method 8081A. Organochlorine Pesticides by Gas Chromatography. Revision 1, US Environmental Protection Agency, Washington DC.

43. Vincevica-Gaile, Z., Stapkevica, M., Stankevica, K., \& Burlakovs, J. (2015). Testing sapropel (gyttja) as soil amendment: assessment of plant germination and early seedling development In: Proceedings of Research for Rural Development, 1, 88 - 94.

44. Vircavs, M. (2006). Sediment quality assessment in Latvia water bodies (Conference Paper) IEEE US/ EU Baltic International Symposium, BALTIC 2006, Category numberCFP06AME-ART; Code 118161.

45. Vorkamp, K. (2016). An overlooked environmental issue? A review of the inadvertent formation of PCB11 and other PCB congeners and their occurrence in consumer products and in the environment. Science of The Total Environment, 541, 1463 - 1476.

46. Wang, Z., \& Fingas, M. (2005). Oil and petrpleum product fingerprinting analysis by gas chromatographic techniques. In: Chromatographic analysis of the Environment. Third edition. (Ed. Leo M.L. Nollet) Taylor \& Francis, Ghent, Belgium, 1028 - 1103.

47. 47. Wetzel, R.G. (2001). Past productivity: paleolimnology. In: (Ed. Wetzel, R.G.), Limnology. Lake and River Ecosystems, Third edition. Elsevier, Oxford, pp. 785 - 804.

48. 48. Yenn, R. (2015). A study on problems associated with crude oil contamination in Assam and its control using biological methods. Laxmi Book Publication, India, $210 \mathrm{pp}$. 